\author{
Przemystaw Pomykalski* \\ Maciej Domagalski**
}

\title{
IPO UNDERPRICING AND FINANCIAL ANALYSTS' FORECAST ACCURACY IN POLAND
}

\begin{abstract}
We review the theory and evidence on IPO activity and underpricing focusing on the Warsaw Stock Exchange and confirm that many IPO phenomena in Poland are not stationary. Focusing on the behavioural reasons for underpricing, we investigate the accuracy of analysts' valuations made prior to initial public offerings. Using a unique set of data, we find a disappointing lack of accuracy, not only in the results of valuations but also in the underlying forecasts of revenues.
\end{abstract}

Key words: IPO, underpricing, Poland, behavioural finance.

\section{INTRODUCTION}

Companies start out by raising equity capital from a small number of investors (founders). During the first years of existence, many companies fail, while others become lifestyle ventures. Some however grow, exploiting business opportunities and attracting further financing. Those prospering companies at some point may seek to „go public" and offer their shares to the general public.

Most companies go public by conducting an Initial Public Offering (IPO). It occurs when a security is sold to the general public for the first time.

Selling shares to the general public requires piquing its interest. As an incentive, shares are offered at a price which is lower than that resulting from valuations. The size of the incentive is difficult to research, as pre-IPO valuations are kept confidential. Usually, the difference between the price at the end of the first day of trading and the price at which shares are sold to new investors (,underpricing”) is used as an indicator.

Data gathered by Jay Ritter indicate that IPO underpricing in the United States fluctuates substantially, averaging $21.2 \%$ in the $1960 \mathrm{~s}, 7.1 \%$ in the $1970 \mathrm{~s}$, $6.8 \%$ in the $1980 \mathrm{~s}, 21 \%$ in the $1990 \mathrm{~s}$, and $22.7 \%$ since $2000^{1}$.

\footnotetext{
* Ph.D., Lodz University of Technology, Faculty of Organization and Management.

** Lodz University of Technology, Graduate.

${ }^{1}$ Based on data available on Jay Ritter's website [http://bear.cba.ufl.edu/ritter/ipodata.htm].
} 
In our study we investigate underpricing in IPOs on the Warsaw Stock Exchange (WSE) between 2005 and 2013. Similar research has been conducted in various countries by Chowdry and Sherman [1996: 359-381], Habib and Ljungqvist [2001: 433-458], Banerjee, Dai and Shrestha [2011: 1289-1305], Chan, Wang and Wei [2004: 409-430] in China, Cassia et al [2004: 179-194] in Italy, Chambers and Dimson in the UK [2009: 1407-1443], Boubaker and Mezhoud in France [2012: 166-180], and Ganesamoorthy and Shankar in India [2013: 84-100].

Further, we also investigate the accuracy of analysts' recommendations published prior to IPOs. Both individual and institutional investors take into consideration the market analyses conducted by brokerage houses in their decisions on whether to buy shares in an IPO. According to Zarzecki and Matecki [2006: 261-274], this hypothesis applies particularly to young and emerging markets of which the Polish capital market still belongs [Różański and Kaźmierska-Jóźwiak 2009: 299-308]. The majority of analysts' recommendations consider companies already quoted on either of Warsaw Stock Exchange's lists. Yet only a fraction of all published reports refer to initial public offerings. Zarzecki and Matecki [2006: 261-274], in a comprehensive research, analysed in total eighty one reports published from March 20th 2001 to December 16th 2005, only seven of which referred to IPOs. We focused on IPO and analysed 30 IPO related reports.

Ljungqvist [2005: 1759-1790] pointed out that the vast majority of theoretical work in the area builds on the premise that market participants are rational and maximize expected utility, subject to market frictions (asymmetric information being most widely examined). The behavioural perspective represents an alternative to the asymmetric information approach [Lamont and Taler 2003: 227-268], [Liungqvist, Nanda, Singh 2006: 1667-1702]. In this paper we investigate optimistic and pessimistic approaches to the revenue forecasting assumed by analysts in pre IPO valuations.

Our results indicate that the average underpricing of IPOs on WSE in the period 2005-2013 was $11.89 \%$. This varied over the years and depended on the size of the offer. We found analysts' recommendations to be inaccurate, especially in forecasting revenues. Furthermore, we found that analysts tended to be over-optimistic in revenue forecasts for the second and third year of the forecast.

The paper proceeds as follows. We start by summarizing the basic facts and research conclusions referring to the Warsaw Stock Exchange. We believe this background is essential in the analysis of behaviour in financial markets due to social and cultural differences. We then move to the description of data and methodology, dividing it into two parts - one related to underpricing and one related to analysts' recommendations. We follow this with the analysis and discussion of the results and conclusions. 


\section{THE WARSAW STOCK EXCHANGE}

The underpricing of IPOs has been a topic of theoretical investigation for decades. Although the world economy seems to be financially integrated, direct comparison of IPO data from different countries may be misleading [Ritter 2003: 421-434]. Differences in the market capitalization of companies quoted, daily turnover and the impact of institutional and foreign investors are obvious. Less obvious differences result from behavioural factors, which are difficult to explain using quantitative data.

Although capital markets in Poland can be traced back to 1817, Warsaw Stock Exchange (WSE) only restarted operations in 1991. Trading is conducted on three markets: The Main List, New Connect (for smaller companies) and Catalyst (for debt instruments). In this paper we focus on the Main List. The number of companies traded on the Main List reached 450 in 2013 and market capitalization is approaching 600 billion PLN (Graph 1). A thorough analysis of the development of WSE was recently published by Kołosowska [2013].

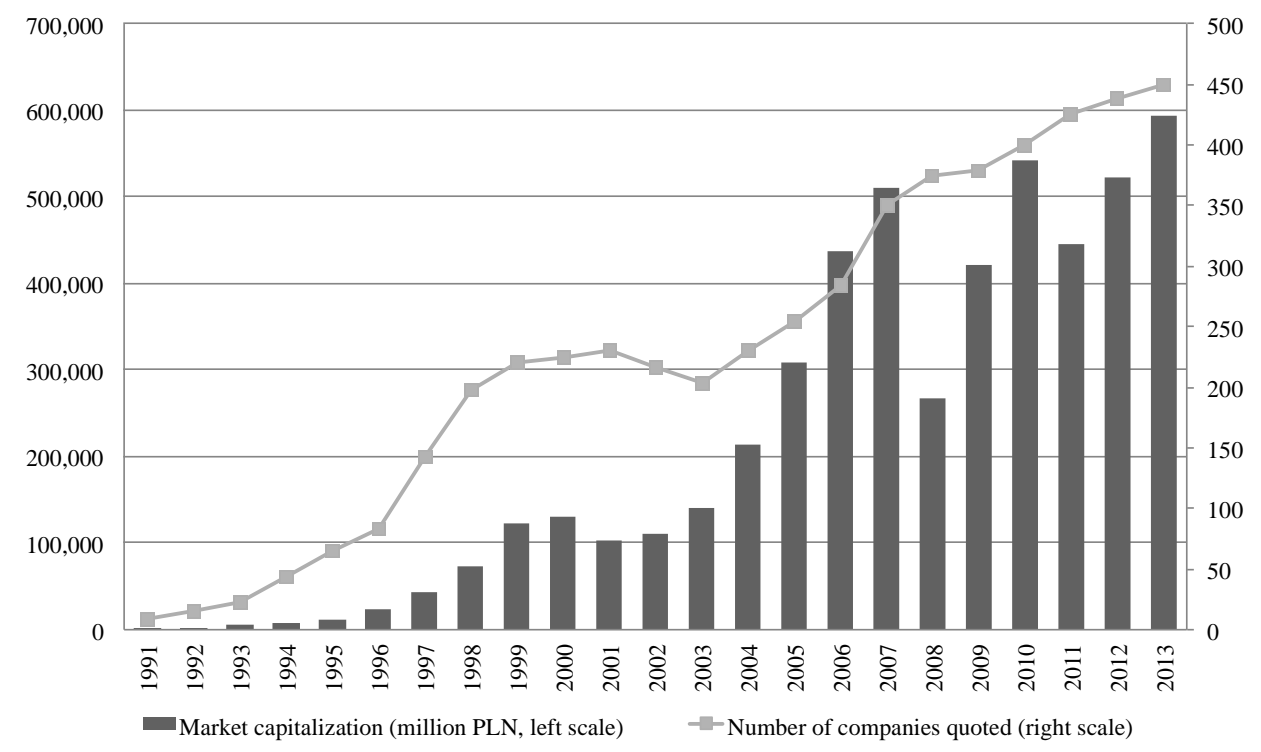

Graph 1. Cumulative abnormal returns for STOXX Europe Sustainability index inclusion Source: own elaboration.

The WSE is growing but is described as thinly traded [Brzeszczyński, Bohl, Serwa 2012: 32-33]. Recent studies indicate that the industry structure of the companies quoted on WSE mirrors the Polish economy [Brzeszczynski, Gajdka, Schabek 2009: 3-9]. 
Capital markets and IPO markets are cyclical [Ibbotson and Jaffe 1975: 1027-1042], [Ibbotson, Sindelar, Ritter 1994: 66-74], [Lowry and Schwert 2002: 1171-1200], and the WSE is not an exception, with significant downturns observed in 2001 and 2008.

In the period 1994-2003, annual returns on investment in WIG followed the returns on S\&P 500 but the changes were more volatile (Graph 2).

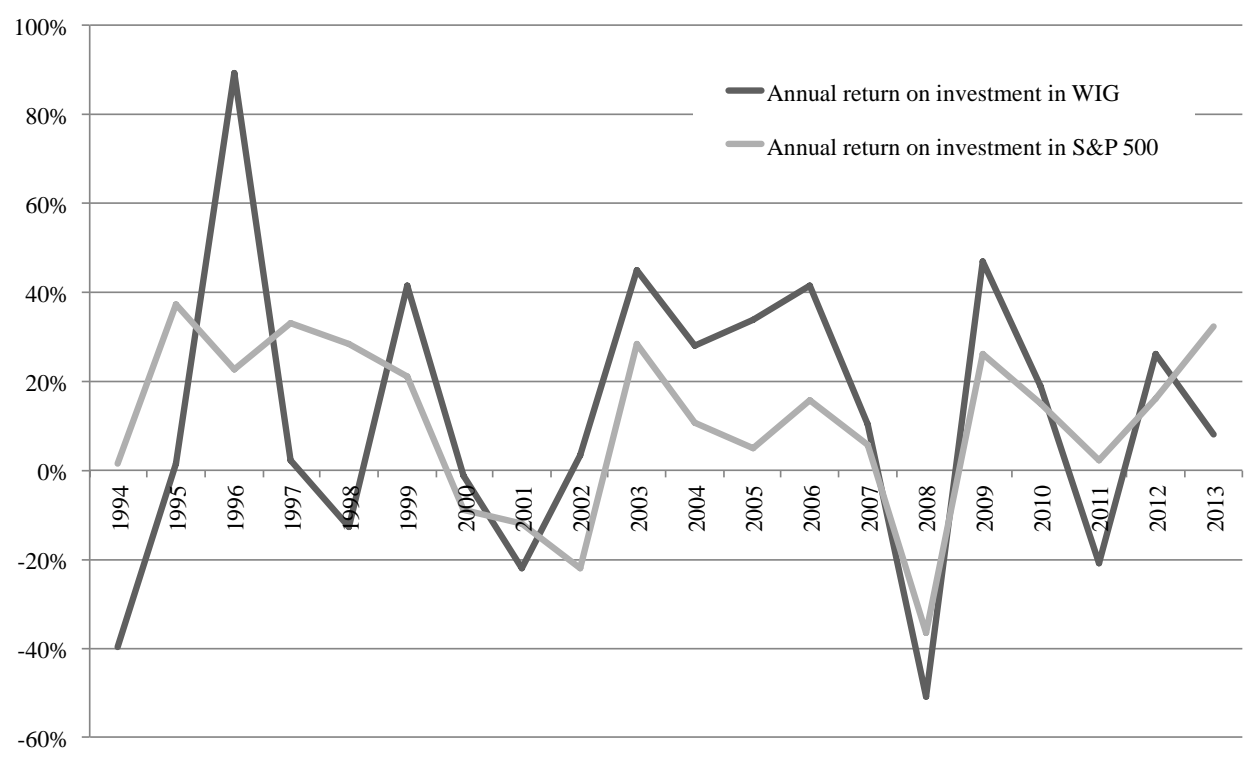

Graph 2. Annual returns on investment in WIG and S\&P 500

Source: own elaboration.

\section{DATASET AND METHODOLOGY}

The dataset consists of 254 IPOs conducted on the Main List of the Warsaw Stock Exchange in the years 2005-2013. We excluded securities that have previously been offered on other markets. In this period, all companies and analysts adhered to International Financial Reporting Standards (IFRS).

Our research of analysts' recommendations required imposing the following constraints:

- The time period was limited to 2005-2010. The research periods ends in 2010 as forecasts were compared to actual results 2 years into the future.

- Only reports prepared by brokerage houses were included.

- Only reports that included multiples and DCF valuation method results were included. 
Table 1. Number of IPOs in the dataset

\begin{tabular}{|c|c|c|c|c|c|c|c|c|c|}
\hline Year & 2005 & 2006 & 2007 & 2008 & 2009 & 2010 & 2011 & 2012 & 2013 \\
\hline \hline No of IPOs included & 35 & 37 & 67 & 25 & 12 & 24 & 28 & 12 & 14 \\
\hline
\end{tabular}

Source: own elaboration.

After applying the assumed criteria, we identified thirty IPO valuation reports (Table 2). All of them were prepared by nine brokerage houses: BDM, DM BGŻ, DM BOŚ, DM BZWBK, Millenium DM, DM Penetrator, DM PKO BP, DM Polonia and IDM. Importantly, 28 out of the 30 recommendations were published by underwriters.

Table 2. Number of recommendations in the dataset

\begin{tabular}{|c|c|c|c|c|c|c|}
\hline Year & 2005 & 2006 & 2007 & 2008 & 2009 & 2010 \\
\hline \hline No of IPOs included & 8 & 8 & 9 & 1 & 3 & 1 \\
\hline
\end{tabular}

Source: own elaboration.

In the analysis of the accuracy of revenue forecasts, 5 recommendations had to be excluded (due to lack of data for comparison).

\subsection{IPO underpricing}

In our analysis of IPO underpricing we apply the methodology of first day return, which does not differ from what may be found in IPO-related literature [Ritter 2003: 421-434], [Zarzecki and Matecki 2006: 261-274]. The computation follows the simple investment return rate equation:

$$
I R_{i, t}=\frac{P_{i, t}-P O_{i}}{P O_{i}}
$$

where:

$I R_{i . t}$ - denotes initial return for the investor on a particular IPO,

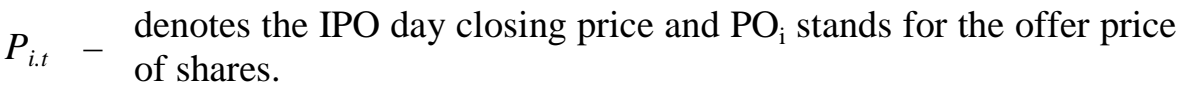

Some authors suggest applying WIG adjustment to the price [Czapieski, Jewartowski, Kałdoński, Mizerka 2011: 31-33] but this view is not popular. We use simple return rates to allow for comparison. 


\subsection{Investigation of recommendations}

The method of precision determination employed by Zarzecki and Matecki [2006: 261-274] was adopted to perform this part of the investigation. The authors compared the prices recommended by reports with the real stock quotes at three specified moments: on the day of recommendation, six months after its publication, and directly preceding the publication of this article. One modification had to be done - instead of current stock prices (which were obviously not known for IPO related analyses), issuing prices were examined. Two pricing methods were evaluated: discounted cash flows (DCF) and multiples, as suggested by Ritter and Kim [1999: 409-437] and Roosenboom [2012: 1653-1664]. Whereas the DCF method in the examined reports always resulted in a single price, multiples valuation frequently provided for a range of prices. In those cases the arithmetic average was calculated. We assume that the valuation is ,accurate" if the value calculated by analysts didn't differ by more than $10 \%$ from the market price.

Womack [1996: 137-167], Capstaff, Paudyal and Rees [1999: 3-16], Barber et al. [2001: 88-96], Asquith, Mikhail and Au [2005: 245-282], Loh and Mian [2006: 455-483], Bradley, Jordan and Ritter [2008: 101-133] used similar assumptions in their analyses of brokerage recommendations on different markets. Houston, James and Kacerski [2006: 111-138] further investigated the methods used by analysts to establish target prices and whether the comparable firms used to support target prices are helpful in explaining IPO offer prices. We chose to investigate the analysts' revenue forecast accuracy in DCF valuation models.

\section{RESULTS AND DISCUSSION}

We divide the analysis of our results into two parts: IPO underpricing and analysts' recommendations. The first part is intended to confirm the existence of underpricing and to assess its value. The second part aims at providing for the assessment of the accuracy of analysts' recommendations.

\subsection{IPO underpricing on the Warsaw Stock Exchange}

177 out of 254 IPOs were underpriced, while in 12 the stock price at the end of the first day of trading was equal to the selling price, and 65 provided negative returns on the first day of trading. The average underpricing in the period 2005-2013 was $11.89 \%$, although we found that it varied with time and depended on the size of the offer. 


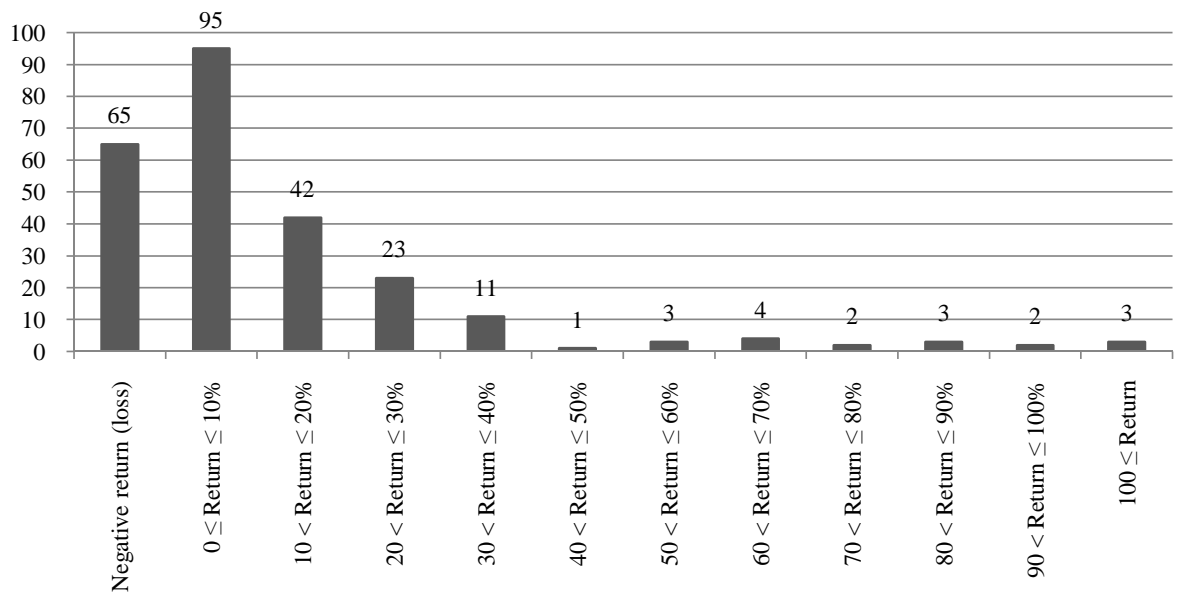

Graph 3. Number of IPOs with initial return breakdown. Warsaw Stock Exchange (2005-2013)

Source: own elaboration.

Underpricing changed significantly over the chosen years (Graph 3). The highest average value of underpricing was observed in 2006 when 37 IPOs brought an ,immediate” on average return of $28.44 \%$. In 2008, following the global economic downturn, negative levels of underpricing were observed.

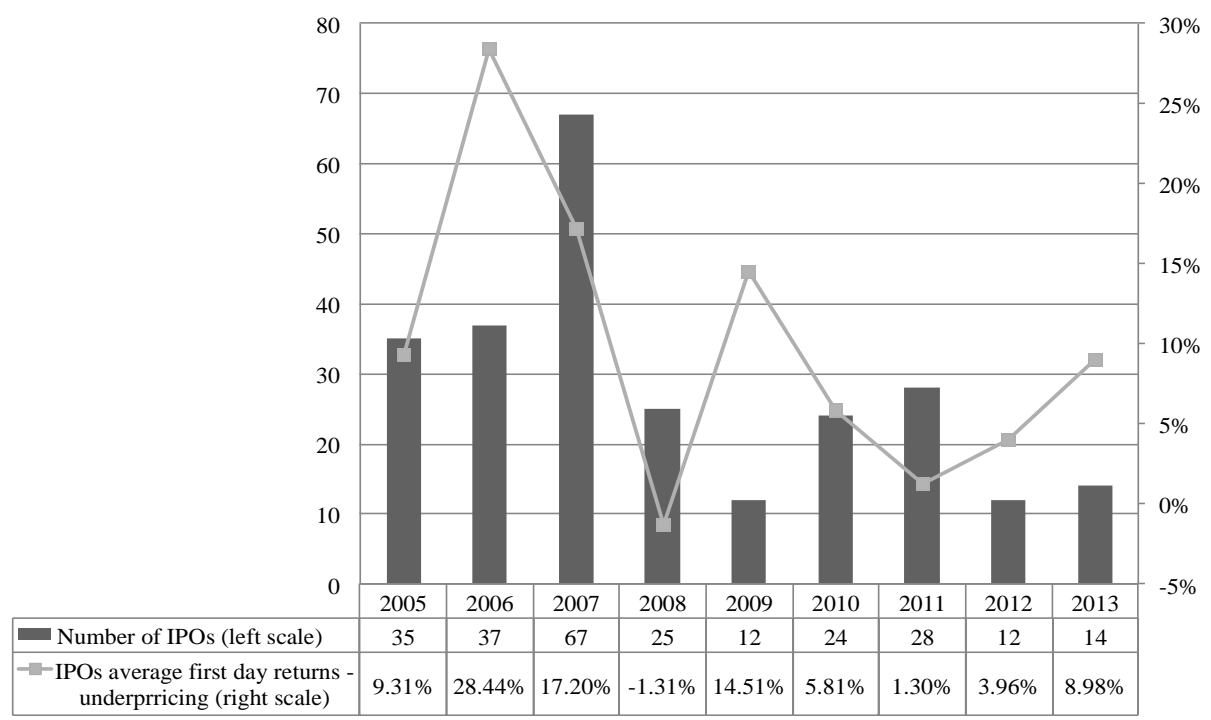

Graph 4. Number and average of first day return on IPOs. Warsaw Stock Exchange (2005-2013) Source: own elaboration. 
This confirms the results of earlier studies on other markets. We also found that underpricing fluctuates with the size of the offer.

On the WSE, the vast majority (83\%) of companies do not collect more than 250 million PLN from the market during an initial public offering. It's these, "smallest", IPOs which are underpriced to the largest extent (12.78\%). The average difference between offer price and first day closing is smaller for larger offerings. For the small group of the biggest IPOs (more than 750 million PLN), the level of underpricing rises again. Most of those largest offerings (11 out of 17) were privatization related IPOs.

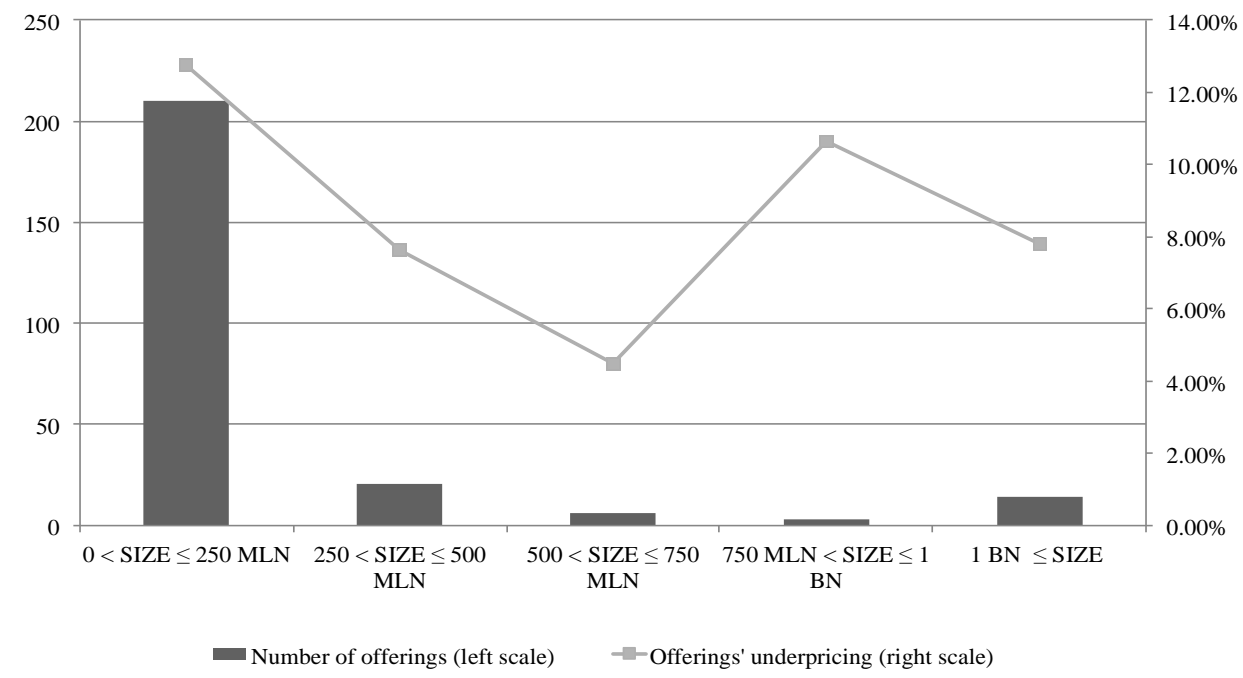

Graph 5. Number of IPOs and the average initial return in a breakdown by size of offering Source: own elaboration.

The significance of underpricing is represented by the ,money left on the table". It is calculated as the number of shares sold multiplied by the difference between the first day closing price and the issuing price. Evidently, the total money that pre-IPO shareholders and companies decided to sacrifice in order to attract potential investors to buy shares, decreased rapidly after 2010. Fluctuations in the total value of money left on the table have also been observed by Loughran and Ritter [2002: 413-444], whose explanation considers the prospect and hot issue market theories. The prospect theory focuses on a positive change in the wealth of the issuers, whereas the hot market theory assumes that more money left on table follows recent market rises and not necessarily market falls. While we do not find clear evidence of any hot issue market for our dataset, an investigation of prospect theory [Ljungqvist, Wilhelm 2005: 1759 $-1790]$ may be an interesting field of further research. 


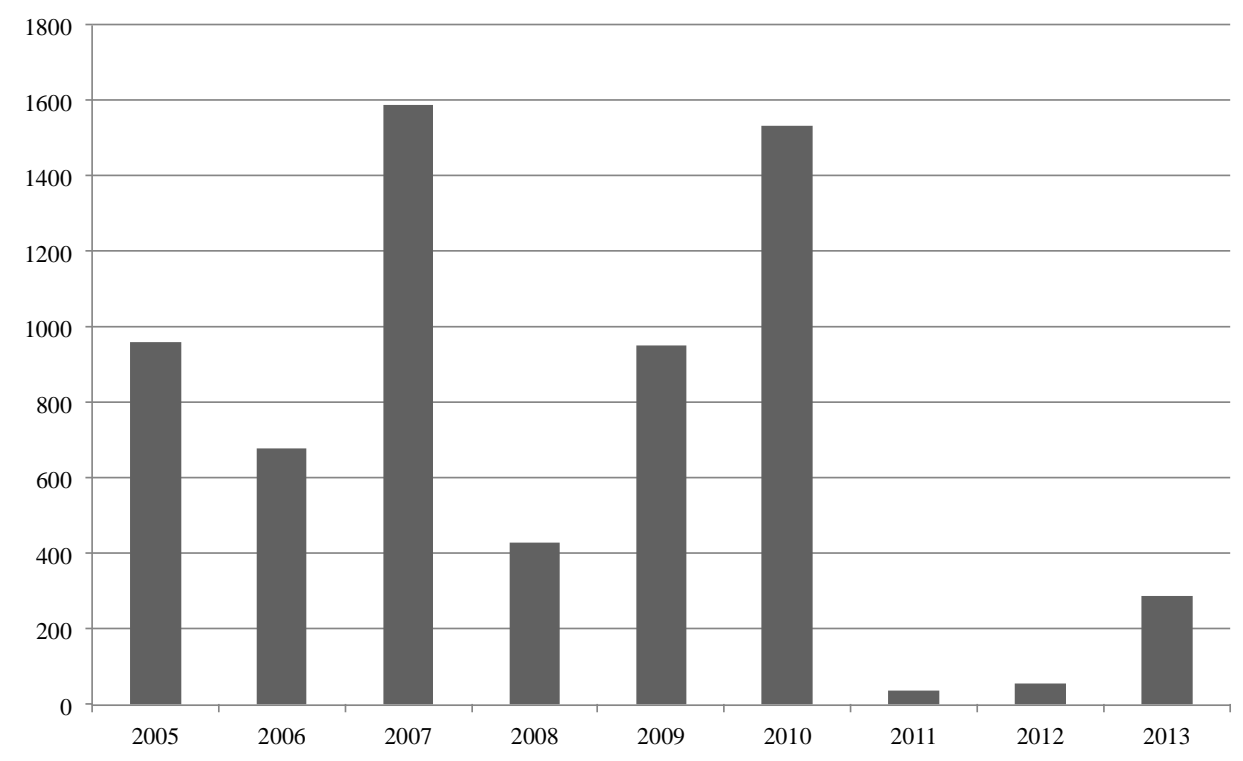

Graph 6. Total value of money left on the table (in million PLN)

Source: own elaboration.

\subsection{Analysts' recommendations}

Firstly, the spread between the initial offering price and the effects of brokerage houses' pricing attempts was examined. When the DCF valuation method was applied, $80 \%$ of all IPOs were priced higher than their initial offering price. Multiples valuation priced IPOs even more optimistically, $87 \%$ of reports provided a higher price. Interestingly, only two valuations did not differ from that which was eventually proposed to the market as a subscription price. Comparing the results of the valuation methods applied, multiples results were on average overpriced by $19 \%$, while DCF results were overpriced by $17 \%$, with a standard deviation of 0.18 and 0.23 respectively.

Since the database allowed for coupling recommendation details with historical stock quotes, the precision could be investigated at several points of time. In Graph 7, we present the percentage of the valuation prices that turned out to be correct a specified number of days after IPO. Our analysis indicates that compared to the closing price on the first day of secondary market trade, prices recommended by multiples valuations did not differ from offering price by more than $10 \%$ for only nine out of thirty cases. DCF valuations turned out to be only a little more precise - in eleven out of thirty cases this method indicated the price precisely. Forty percent of recommendations did not differ from the 
actual stock prices by more than $10 \%$ two weeks after the IPO. After half a year (assumed elapse time: 120 trading days from the IPO), only 17\% of all multiple valuations indicated the price close to reality, while only one tenth of DCFs provided such precision.

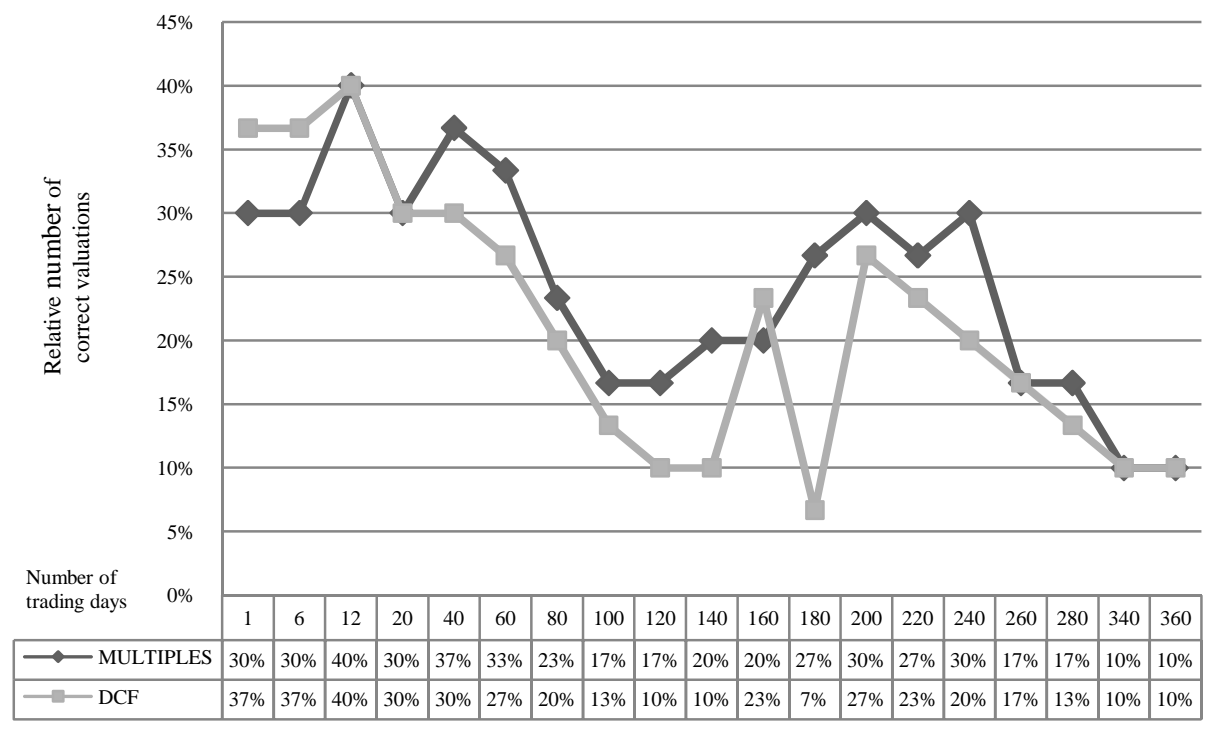

Graph 7. Dispersion of differences between valuations and historical prices (in trading days following IPOs)

Source: own elaboration.

Historical analysis of aggregated revenue behaviour indicates that although revenues tend to grow after IPO, the dynamics of this growth decreases. This conclusion is consistent with previous observations by Brav and Gompers [1997: 1791-1821]. Revenue behaviour greatly influences valuation methods, particularly, discounted cash flows. As indicated by Hirsher [2011: 156], EBITDA, depreciation, capital expenditures, and changes in NWC - components that by definition directly influence cash flow forecasts - are obtained with the use of the ratio of sales method. Such observations fully justify investigation of revenue behaviour and forecasting accuracy when analyzing IPO valuations.

Four estimated figures were collected from 25 brokerages' valuations: revenue in the year of IPO - Y0 (annual results covering the year of initial offering are published in following year), and the following three reported years $(+\mathrm{Y} 1,+\mathrm{Y} 2,+\mathrm{Y} 3)$. Historical values of company revenues, which had been actually presented in the original financial statements, were coupled with numbers derived from brokerages' DCF models. 
All brokerage houses' recommendations were prepared before companies published the results of an IPO's financial year (Y0) itself. Although underwriters had virtually unlimited access to a company's financial statements (as their representatives, they played an active role during the process of price determination and the following book building), even forecasts of $\mathrm{Y} 0$ turned out to be inaccurate. Only 16 out of 25 forecasts when considering the first year were precise (we understand a precise forecast not to differ by more than 10\%). The range of relative errors for particular years is presented in Table 3. Each column consists of errors sorted in an ascending manner.

Table 3. Relative revenue forecast errors for particular years after IPO in ascending order

\begin{tabular}{|c|c|c|c|c|}
\hline & $\begin{array}{c}\text { Relative } \\
\text { forecast } \\
\text { errors } \\
+Y 0 \\
\text { (ascending } \\
\text { order) }\end{array}$ & $\begin{array}{c}\text { Relative } \\
\text { forecast } \\
\text { errors } \\
+Y 1 \\
\text { (ascending } \\
\text { order) }\end{array}$ & $\begin{array}{c}\text { Relative } \\
\text { forecast } \\
\text { errors } \\
+\mathrm{Y} 2 \\
\text { (ascending } \\
\text { order) }\end{array}$ & $\begin{array}{c}\text { Relative } \\
\text { forecast } \\
\text { errors } \\
+Y 3 \\
\text { (ascending } \\
\text { order) }\end{array}$ \\
\hline & $-27.55 \%$ & $-37.67 \%$ & $-60.00 \%$ & $-65.88 \%$ \\
\hline & $-19.43 \%$ & $-28.92 \%$ & $-44.52 \%$ & $-61.28 \%$ \\
\hline & $-18.84 \%$ & $-19.21 \%$ & $-32.83 \%$ & $-59.54 \%$ \\
\hline & $-13.72 \%$ & $-15.87 \%$ & -30.85 & $-49.43 \%$ \\
\hline & $-9.78 \%$ & $-15.12 \%$ & $-29.13 \%$ & $-39.78 \%$ \\
\hline & $-5.41 \%$ & $-12.50 \%$ & $-25.84 \%$ & $-36.02 \%$ \\
\hline & $-4.35 \%$ & $-10.90 \%$ & $-25.54 \%$ & $-34.11 \%$ \\
\hline & $-4.11 \%$ & $-5.63 \%$ & $-22.47 \%$ & $-29.10 \%$ \\
\hline & $-3.68 \%$ & $-5.33 \%$ & $-18.78 \%$ & $-20.15 \%$ \\
\hline & $-1.76 \%$ & $-2.54 \%$ & $-17.98 \%$ & $-16.04 \%$ \\
\hline & $-1.13 \%$ & $-1.85 \%$ & $-6.66 \%$ & $-7.93 \%$ \\
\hline & $-0.72 \%$ & $0.13 \%$ & $1.04 \%$ & $-0.71 \%$ \\
\hline & $-0.56 \%$ & $1.01 \%$ & $2.06 \%$ & $-0.24 \%$ \\
\hline & $0.32 \%$ & $2.97 \%$ & $5.05 \%$ & $8.88 \%$ \\
\hline & $1.77 \%$ & $5.38 \%$ & $6.36 \%$ & $12.91 \%$ \\
\hline & $2.79 \%$ & $6.05 \%$ & $6.46 \%$ & $13.66 \%$ \\
\hline & $3.08 \%$ & $6.16 \%$ & $17.32 \%$ & $14.02 \%$ \\
\hline & $3.24 \%$ & $10.09 \%$ & $19.14 \%$ & $17.22 \%$ \\
\hline & $3.69 \%$ & $15.67 \%$ & $19.35 \%$ & $22.22 \%$ \\
\hline & $4.25 \%$ & $19.18 \%$ & $21.99 \%$ & $32.38 \%$ \\
\hline & $10.11 \%$ & $22.21 \%$ & $25.88 \%$ & $36.04 \%$ \\
\hline & $15.27 \%$ & $31.89 \%$ & $30.43 \%$ & $38.43 \%$ \\
\hline & $15.72 \%$ & $36.97 \%$ & $33.81 \%$ & $38.43 \%$ \\
\hline & $16.93 \%$ & $37.25 \%$ & $38.12 \%$ & $48.88 \%$ \\
\hline & $25.36 \%$ & $39.17 \%$ & $41.30 \%$ & $51.54 \%$ \\
\hline Total number of analysed forecasts: & 25 & 25 & 25 & 25 \\
\hline Accurate forecasts: & 16 & 10 & 6 & 4 \\
\hline Percent of accurate forecasts: & $64.00 \%$ & $40.00 \%$ & $24.00 \%$ & $16.00 \%$ \\
\hline
\end{tabular}

Source: own elaboration. 
The overall accuracy of forecasts is low from the very beginning, and drastically decreases with time. It is somewhat poor even for Y0 - only in 16 cases out of 25 estimated revenues in the same year in which the IPO was to happen had been correctly foreseen. For 5 companies - revenues turned out to be much higher than expected (a relative error higher than 10\%) while four were overestimated. The highest over- and underestimations were $-27.55 \%$ and $+25.33 \%$ respectively (the negative sign of error denotes overestimation, positive - underestimation. In this example: $-27.55 \%$ relates to the IPO's year's revenues which had been predicted to amount to 57.6 million PLN, against the real reported revenues of 45.12 million PLN). As indicated, the accuracy for the following years decreased. The first years' revenues directly following IPO were forecast accurately only in $40 \%$ of cases. The spread between minimum and maximum errors also suggested lower forecasting quality: maximum over- and underestimations were $37.67 \%$ and $39.17 \%$. The second and third years resulted in an even lower efficiency of forecasters - their predictions were correct in $6(24 \%)$ and $4(16 \%)$ of trials. Shaded cells represent the range of ,acceptable" error: $+/-10 \%$.

Faced with such inaccuracy, it is interesting to check whether published forecasts are overly optimistic or pessimistic in their forecasts. The total number of underestimated figures is 52 , which, compared to a total of 48 overestimations, leads to the conclusion that, generally, forecasters do not follow a clear sentiment on the revenues and are neither especially optimistic nor evidently pessimistic (Graph 8). They are simply inaccurate.

Analysis over the years indicates that while in $\mathrm{Y} 0$ revenues are neither significantly underestimated nor overestimated, in $\mathrm{Y} 1$ and $\mathrm{Y} 2$ the results are slightly underestimated. Interestingly, in $\mathrm{Y} 3$ the results are once again overestimated, and it may be expected that in Y4 and the following years that results would tend to be overestimated. As mentioned above, in the case of DCF valuation, this leads to higher valuations, as later years are used to calculate the terminal value. This indicates that revenue forecasts prepared by analysts are inaccurate. Revenues are overestimated in the later years of the forecasts.

\section{CONCLUSIONS}

A thorough understanding of underpricing is vital for decision-making related to investments in IPOs. We confirm the existence of underpricing on WSE. Our results indicate that on average underpricing in the period 2005-2013 was equal to $11.89 \%$, but varied with time. We observed considerable fluctuations in the total money left on the table. We also found underpricing to be higher for smaller offerings and for privatization related IPOs. 


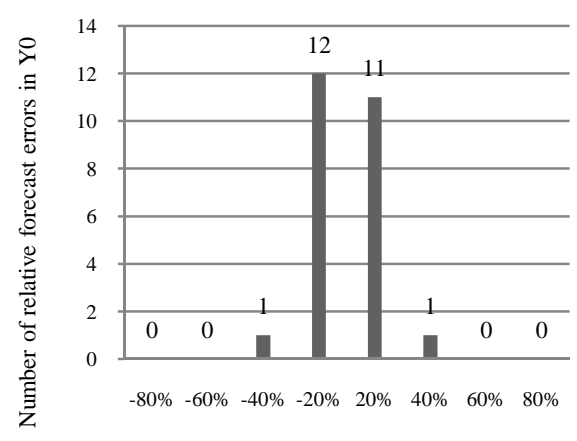

Relative forecast error

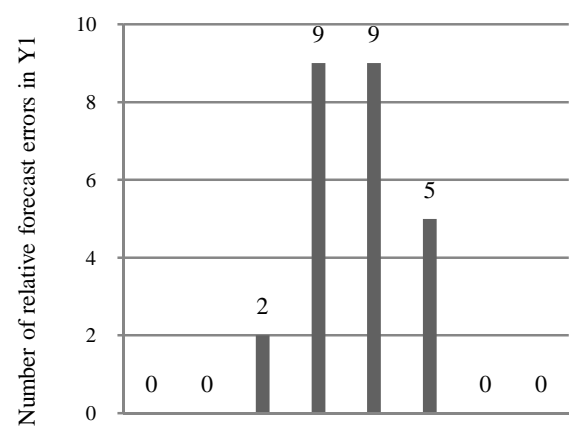

$-80 \%-60 \%-40 \%-20 \% \quad 20 \% \quad 40 \% \quad 60 \% \quad 80 \%$

Relative forecast error

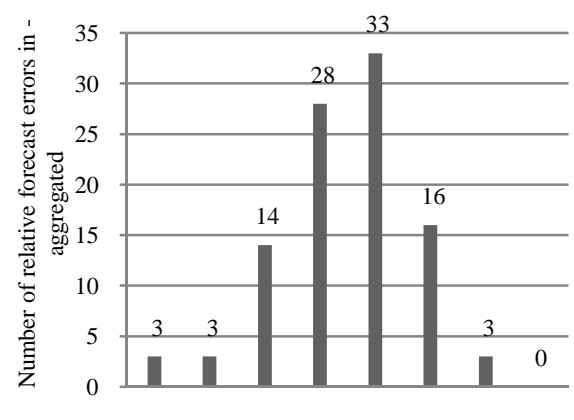

$-80 \%-60 \%-40 \%-20 \% \quad 20 \% \quad 40 \% \quad 60 \% \quad 80 \%$

Relative forecast error
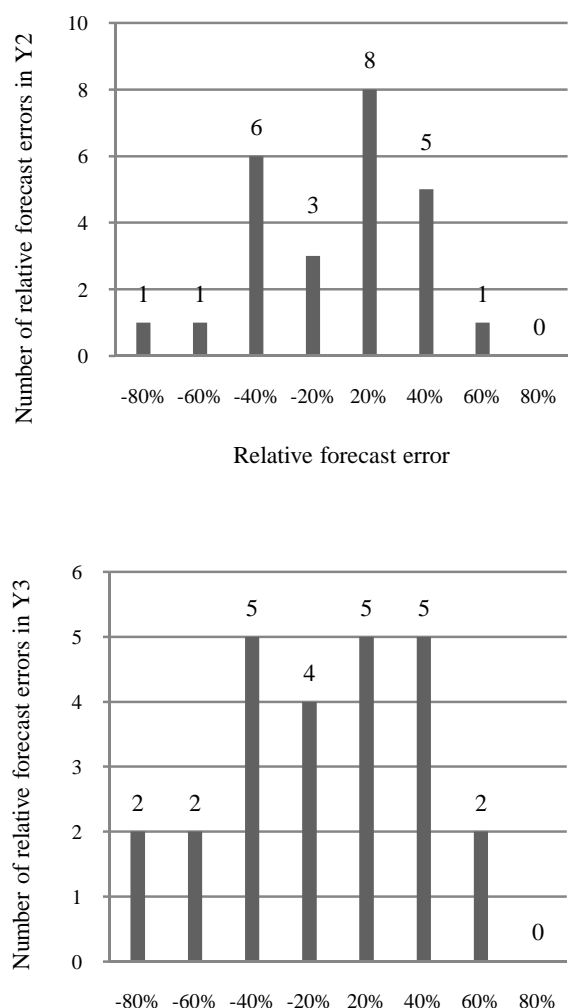

Relative forecast error

Graph 8. Overall and time differentiated distribution of forecasting errors in analysts' revenue forecasts

Source: own elaboration. 
Our findings provide new evidence about the accuracy of revenue forecasts in analysts' recommendations for companies quoted on a relatively thinly traded market. We found that pre-IPO valuations differ substantially from actual first day quotations. Analysts are overestimating the stock value using both multiples and DCF valuations. Analysis of revenue forecasts indicate that analysts are over-optimistic in their long-term forecasts (2-3 years after the IPO).

We believe that the results of this research can benefit investors and analysts. Investors should be aware of; underpricing and its value in recent years; the inaccuracy of recommendations and forecasts prepared by analysts. Analysts should attempt to improve their forecasting methods.

\section{REFERENCES}

Asquith P., Mikhail M., Au A., 2005, Information content of equity analyst reports, Journal of Financial Economics 72(2), 245-282.

Banerjee S., Dai L., Shrestha K., 2011, Cross-country IPOs: What explains differences in underpricing?, Journal of Corporate Finance 17(5), 1289-1305.

Barber B., Lehavy R., McNichols M., Trueman B., 2003, Reassessing the Returns to Analysts' Stock Recommendations, Financial Analysts Journal 59(2), 88-96.

Boubaker A., Mezhoud M., 2012, Determinants of the IPO Decision: French Context, Journal of Business Studies Quarterly 4(1), 166-180.

Bradley D. J., Jordan B. D., Ritter J. R., 2008, Analyst behavior following IPOs: The "bubble period" evidence, Review of financial studies 21(1), 101-133.

Brav A., Gompers P. A., 1997, Myth or Reality? The Long Run Underperformance of Initial Public Offerings: Evidence from Venture and Nonventure Capital Backed Companies, The Journal of Finance 52(5), 1791-1821.

Brzeszczyński J., Gajdka J., Schabek T., 2009, Koniunktura giełdowa a zmiany w realnej sferze gospodarki w Polsce, Przegląd Organizacji 7(8), 3-9.

Brzeszczyński J., Bohl M., Serwa D., 2012, Large capital inflows and stock market in a thin market, National Bank Of Poland Working Paper 120, 3-30.

Capstaff J., Paudyal K., Rees W., 1999, The relative forecast accuracy of UK brokers, Accounting and Business Research 30(1), 3-16.

Cassia L., Giudici G., Paleari S., Redondi R., 2004, IPO underpricing in Italy, Applied Financial Economics 14(3), 179-194.

Chan K., Wang J., Wei K., 2004, Underpricing and long-term performance of IPOs in China, Journal of Corporate Finance 10(3), 409-430.

Chambers D., Dimson E., 2009, IPO underpricing over the very long run, The Journal of Finance 64(3), 1407-1443.

Chowdhry B., Sherman A., 1996, International differences in oversubscription and underpricing of IPOs, Journal of Corporate Finance 2(4), 359-381.

Czapiewski L., Jewartowski T., Kałdoński M., Mizerka J., 2011, Determinanty natychmiastowych stóp zwrotu z akcji spótek skarbu państwa dokonujacych pierwotnych ofert publicznych, Unpublished manuscript, 1-33.

Ganesamoorthy L., Shankar H., 2013, The Performance of Initial Public Offerings Based on Their Size: An Empirical Analysis of the Indian Scenario, IUP Journal of Applied Finance 19(4), 84-99.

Habib M., Ljungqvist A., 2001, Underpricing and entrepreneurial wealth losses in IPOs: Theory and evidence, Review of Financial Studies 14(2), 433-458.

Hirsher J. R., 2011, Financial Valuation, Hoboken, New Jersey, 156. 
Houston J., James C., Karceski J., 2006, What a difference a month makes: Stock analyst valuations following initial public offerings, Journal of Financial and Quantitative Analysis 41(1), 111-138.

Ibbotson R., Jody L., Ritter J., 1988, Initial public offerings, Journal of Applied Corporate Finance $1,37-45$.

Ibbotson R., Jody L., Ritter J., 1994, The market's problems with the pricing of initial public offerings, Journal of Applied Corporate Finance 7, 66-74.

Kołosowska B., 2013, Finansowanie sektora matych i średnich przedsiębiorstw poprzez rynek kapitałowy w Polsce, Warszawa.

Lamont O. A., Thaler R. H., 2003, Can the Market Add and Subtract? Mispricing in Tech Stock Carve-outs, The Journal of Political Economy 111(2), 227-268.

Ljungqvist A., Wilhelm W. J., 2005, Does prospect theory explain IPO market behavior?, The Journal of Finance 60(4), 1759-1790.

Ljungqvist A., Nanda V., Singh R., 2006, Hot Markets, Investor Sentiment, and IPO Pricing, The Journal of Business 79(4), 1667-1702.

Ljungqvist A., 2007, IPO Underpricing, In: B. Espen Eckbo (ed.), Handbook in Corporate Finance: Empirical Corporate Finance, North-Holland.

Loh R., Mian M., 2006, Do accurate earnings forecasts facilitate superior investment recommendations?, Journal of Financial Economics 80(2), 455-483.

Lowry M., Schwert W., 2002, IPO market cycles: Bubbles or sequential learning?, The Journal of Finance 57(3), 1171-1200.

Loughran T., Ritter J., 2002, Why Don't Issuers Get Upset About Leaving Money on the Table in IPOs?, Review of Financial Studies 15(2), 413-444.

Ritter J., Kim M., 1999, Valuing IPOs, Journal of Financial Economics 53(3), 409-437.

Ritter J., Welch I., 2002, A review of IPO activity, pricing, and allocations, Journal of Finance $57(4), 1795-1828$.

Ritter J., 2003, Differences between European and American IPO markets, European Financial Management 9(4), 421-434.

Roosenboom P., 2012, Valuing and pricing IPOs, Journal of Banking \& Finance 36(6), 1653-1664.

Różański J., Kaźmierska-Jóźwiak B., 2009, Behawioralne aspekty podejmowania decyzji inwestycyjnych na warszawskiej giełdzie papierów wartościowych, In: A. Szablewski, R. Wójcikowski (eds.), Rynki kapitałowe a koniunktura gospodarcza, Łódź.

Womack K., 1996, Do Brokerage Analysts' Recommendations Have Investment Value?, Journal of Finance 51(1), 137-167.

Zarzecki D., Matecki T., 2006, Rekomendacje biur maklerskich - próba analizy, Zarządzanie finansami, Szczecin.

\section{Pzemystaw Pomykalski, Maciej Domagalski}

\section{NIEDOSZACOWANIE CEN EMISYJNYCH PIERWSZYCH OFERT PUBLICZNYCH AKCJI ORAZ DOKŁADNOŚĆ PROGNOZ ANALITYKÓW W POLSCE}

W artykule dokonujemy przeglądu teorii, cech aktywności i niedoszacowania cen emisyjnych (IPO underpricing) pierwszych ofert publicznych na Rynku Głównym Giełdy Papierów Wartościowych w Warszawie. Potwierdzamy, iż wiele zjawisk związanych z IPO nie ma charakteru stałego. Bazując na behawioralnych aspektach niedoszacowania cen emisyjnych akcji weryfikujemy dokładność wycen giełdowych sporządzanych przez analityków przed pierwszymi ofertami publicznymi. Analizując bazę danych stworzoną na potrzeby artykułu obserwujemy rozczarowujący brak dokładności nie tylko w zakresie wycen spółek, ale także w prognozach przychodów, na których owe wyceny bazują.

Słowa kluczowe: IPO, oferty publiczne, Polska, finanse behawioralne. 